\title{
Change Management in the Higher Education Context: A Case of Student-centred Learning Implementation
}

\author{
Bhina Patria ${ }^{1,2, *}$
}

${ }^{1}$ Faculty of Psychology, Universitas Gadjah Mada, 55281 Yogyakarta, Indonesia

${ }^{2}$ International Centre for Higher Education Research Kassel (INCHER-Kassel), Moenchebergstrasse 17, Kassel 34109, Germany

*Correspondence: Faculty of Psychology, Universitas Gadjah Mada, Jl. Humaniora No. 1 Bulaksumur 55281 Yogyakarta, Indonesia

E-mail: patria@ugm.ac.id or patria@incher.uni-kassel.de

Received: October 9, 2012 Accepted: November 11, 2012 Published: December 4, 2012

doi:10.5296/ije.v4i4.2515 URL: http://dx.doi.org/10.5296/ije.v4i4.2515

\begin{abstract}
This paper is concerned with the process of change in the university context and examines it through an Indonesian case study. It starts with a review of literature on higher education as an organization, its characteristics, and change management in higher education institutions. The theoretical analysis followed by a case study of student-centred learning (SCL) implementation in the University of Gadjah Mada (UGM), Indonesia. Based on what has been achieved, it has been concluded that the implementation of SCL in UGM is a qualified success and is a good example of change management in higher education context.
\end{abstract}

Keywords: change management; higher education; student-centred learning; SCL; teacher-centred learning 


\section{Introduction}

Higher education institutions are under pressure to change. The pressure for higher education institutions to change comes from a number of interrelated factors: the movement to a mass educational system, a student profile that is changing to include mature students (lifelong learning), growing pressure from industry to produce graduates with both thinking and practical skills, forced competition between higher education institutions to recruit more students to secure survival, and the demand of high quality research (Elton, 1999, 2003; Findlow, 2012; Fremerey, 2006; Grant, 2003; Rebora \& Turri, 2010).

Nevertheless, creating change in the context of organization is not an easy task, moreover in a complex organizational setting like a higher education institution (Fremerey, 2006; Grant, 2003; Guskin, 1996). Higher education institutions are known to have unique characteristics which distinguish them from other organizations. Baldridge (1983), in his paper entitled Organizational Characteristics of Colleges and Universities, identified the characteristics: goal ambiguity, highly contested goals, client-serving institutions, problematic technologies, high professionalism, fragmented professional staff, and environmentally vulnerable.

Apart from these specific characteristics, researchers have classified higher education institutions as organized anarchies (e.g., Baldridge, 1983; Baldridge, Curtis, Ecker, \& Riley, 1982; Giesecke, 1991) and loosely coupled organizations (e.g., Glassman, 1973; Weick, 1976).

Cohen, March and Olsen (1972) describe organized anarchies as organizations which are characterized by problematic preferences, unclear technology, and fluid participation. Giesecke (1991) highlights further that higher education institutions have problematic goals because the organization appears to operate on a variety of inconsistent and ill-defined preferences. Higher education institution members do not always understand organizational process and therefore run on a trial-and-error basis. This is why higher education institution seen as having unclear technology. In explaining the fluid participation, Giesecke (1991) stated that higher education institutions' staffs also vary among themselves in the amount of time and effort they devote to the organization.

Classical literature has categorized universities as loosely coupled organizations. Weick (1976) stated that the word "coupling” has more components than synonymous words such as connection, link, or interdependence. Loose coupling means that the connection between two elements are responsive but at the same time each element preserves its own identity and to some extent still has its physical or logical separateness (Weick, 1976). Weick (1976) also further emphasized: "Loose coupling also carries connotations of impermanence, dissolvability, and tacitness all of which are potentially crucial properties of the 'glue' that holds organizations together" (p. 3).

Even though researchers usually regard loose coupling as a negative matter, in practice there are potential functions that could be associated with loose coupling. Glassman (1973) stated that loose coupling lowers the probability that the organization will have to respond to 
each little change in the environment that happens. A loosely coupled system also provides a sensitive sensing mechanism (Heider as cited in Weick, 1976). The many elements in universities (e.g., faculties, study programs, centre of studies) have the ability to know their environments better than the university as a whole institution. Thus, each element can adapt earlier to any change that occurs in their environment. Weick (1976) further added that loose coupling helps the organization by: permitting its elements to develop creative solutions; preventing a breakdown of the whole organization by sealing the failure in the specific element of the organization; and allowing more room for self-determination by the actors.

Even though researchers have described higher education institutions as organizations that run in chaos, higher education systems have been running stably. Birnbaum (1989) described that there is a thorough self-correcting mechanism that monitors higher education institution functions and provides attention cues, or negative feedback, to participants when things are not going well. When undesirable circumstances emerge something else will correct it and bring it back on track. This process is called cybernetic controls (Birnbaum, 1989).

With all these unique characteristics, higher education institutions certainly have a different approach in institutional governance, management, and leadership than other organizations. Therefore higher education institutions cannot be handled the same way as other organizations when it comes to change management. This paper discusses the process of change in the higher education context. First, the theoretical review of change processes will be presented followed by the definition of student-centred learning (SCL). Afterwards, the paper will discuss a case study of change management in Indonesia's Gadjah Mada University (UGM), when shifting from teacher-centred learning (TCL) to student-centred learning (SCL).

\section{Process of change}

In explaining the process of change, the work of the "father of social psychology", Kurt Lewin, has often been cited. Lewin (as cited in Elton, 1999) identified three phases in a change process: unfreezing, changing and refreezing.

The situation that is status quo is seen as stable by the majority of those within the organization. To initiate a change, this state must be unfrozen first. To initiate change only through reason and education will not work. Unfreezing must depend on the use of power from outside the organization, e.g. the global trend, governmental policy, and financial constraint. This outside power will reduce the forces opposing change to the point where change can start.

Changing involves a shift in the balance of driving forces and opposing forces, and of support and pressure. During this phase there are two kinds of change agents involved: those who use reason and education and those high in the hierarchy who mainly use power. Successful change will happen only when the duet between those at the top and the bottom achieves the right mixture. 
Refreezing refers to establishing stability after the changes have been made. Without a successful refreezing phase, the change process will not become institutionalised. Elton (1999) further added that very often the resources for creating change are exhausted at the end of change process. This allows resisters to step in and negate the successful change which has been achieved.

Based on Lewin's change process, Fremerey (2006) categorized the change process into three states: present state, transition state, and desired state. Present state, or the state before the change process, is characterized by stability or the status-quo condition. It's also illustrated as a comfort zone for the people within it. This stable condition will continue until a change-force disturbs it.

The transition state, in contrast to the present state, is a condition characterized by a disturbance of the equilibrium, low stability, strong emotional stress and high undirected energy.

The desired state is a condition that is illustrated as 'cloudy' and undefined - a condition that represents a vision which is still far from reality. After the desired state is achieved, the new mindset is accepted by the individual. The individuals return to their comfort zone, in the process of refreezing.

Fremerey (2006) additionally asserted that the states of change suggest three basic circumstances in designing and implementing change management. First, individuals in the process of change often have to be taken out of a state which for them is synonymous with security. Second, leaving the present state and entering the transition state is perceived as a threat which automatically produces resistance. Third, resistance is normal when the future state is not sufficiently clear and convincing.

\section{What is Student-Centred Learning?}

Before further discussing the implementation of student-centred learning (SCL) in the University of Gadjah Mada (UGM), it is important to draw an insight about SCL.

During the past few years, student-centred learning (SCL) has emerged into the policy discourse on higher education. It can be found in many national plans for higher education, in international organization policy and in institutional strategies (Geven \& Attard, 2012).

SCL is usually contrasted with traditional method of teacher-centred learning (TCL). In a teacher-centred approach, the teacher is regarded as the only source of knowledge. The teacher must transfer this knowledge to student by lecturing in the classroom, and is in the main role of the process while the student is in a passive and receptive role.

Brandes and Ginnis (1986) referred to SCL as a learning process which has the following principles: (a) the learner has full responsibility for her/his learning, (b) involvement and participation are necessary for learning, (c) the relationship between learners is more equal, promoting growth and development, (d) the teacher becomes a facilitator and 
resource person, (e) the learner experiences confluence in his education (affective and cognitive domains flow together), and (f) the learner sees himself differently as a result of the learning experience.

Fay (1988) stated that SCL is an approach which recognises the integrity and freedom of an individual and attempts to convert the teaching/learning process accordingly. Fay further elaborated that SCL is more about attitudes and relationships than about systems, and can flourish in a variety of settings including the traditional. Additionally, Fay (1988) stated, "It [SCL] rejects learner dependence and, contrary to popular misconception, does not necessarily stress independence; rather it tries to achieve, on a fully democratic model, interdependence" (p. 8).

In defining SCL, Cannon and Newble (2000) assert that: "Essentially SCL has student responsibility and activity at its heart, in contrast to a strong emphasis on teacher control and coverage of academic content in much conventional, didactic teaching" (p. 16).

Correspondingly, Lea and colleagues (2003) summarised the literature on SCL and concluded that student-centred learning embodies the following principles: (a) a reliance upon active rather than passive learning, (b) an emphasis on deep learning and understanding, (c) increased responsibility and accountability on the part of the student, (d) an increased sense of autonomy in the learner, (e) an interdependence between teacher and learner, (f) mutual respect within the teacher-learner relationship, and (g) a reflexive approach to the teaching and learning process on the part of both teacher and learner.

Even though the aforementioned definitions have a variety of emphases, researchers seem to agree on the underlying idea that SCL is comprised of: the autonomy of students in the process of learning, students that are actively engaged in the learning process, and a more equal role between student and teacher. Researchers also agree that SCL is related to an active learning environment. Chickering and Gamson (1991) suggested that active learning means that students must talk about what they are learning, write about it, relate it to past experiences, and apply it to their daily lives. Furthermore, students must engage in higher-order thinking tasks such as analysis, synthesis, and evaluation (Bonwell \& Eison, 1991).

\subsection{Comparison of SCL and TCL}

As mentioned earlier, SCL is often contrasted with the conventional or traditional lecture. A large and growing body of literature has investigated the advantage of active learning over a teacher-centred approach. Vaatstra \& De Vries (2007), who investigated the effect of active learning environments on graduates' competencies, reported that graduates from active learning environments assess themselves as having higher competencies than graduates who studied in conventional learning environments.

The opportunity to determine their own condition of learning, to suffer the consequences of bad choices, and to learn from the consequences are valuable ways for students to acquire responsibility. Moreover, SCL also develops skills in group membership and leadership (Boyapati, 2000). There is also growing evidence that SCL activities promote the 
development of higher-order skills such as critical thinking and problem solving (Brush \& Saye, 2000).

The figure from Suwardjono (2005) describes the difference between SCL and the conventional TCL (Figure 1). In the first structure, students do not have direct access to the knowledge. The teacher is seen as the main source of knowledge and the process of transfer only happens in the classroom. Students take note of all that the teacher says and these notes will be the main substance of the final examination. The second structure shows the essence of SCL in which students actively acquire the knowledge. Student and teacher are in the same position in term of accessing the knowledge. Knowledge is a free domain that can be accessed by both teacher and student. In SCL, the class-meeting is not the place where the teacher provides knowledge to the students, but rather a place where both of them confirm their knowledge (Suwardjono, 2005). The application of SCL was translated into several methods of teaching and learning such as: collaborative learning, cooperative learning, problem-based learning, case-based learning, and competitive learning.

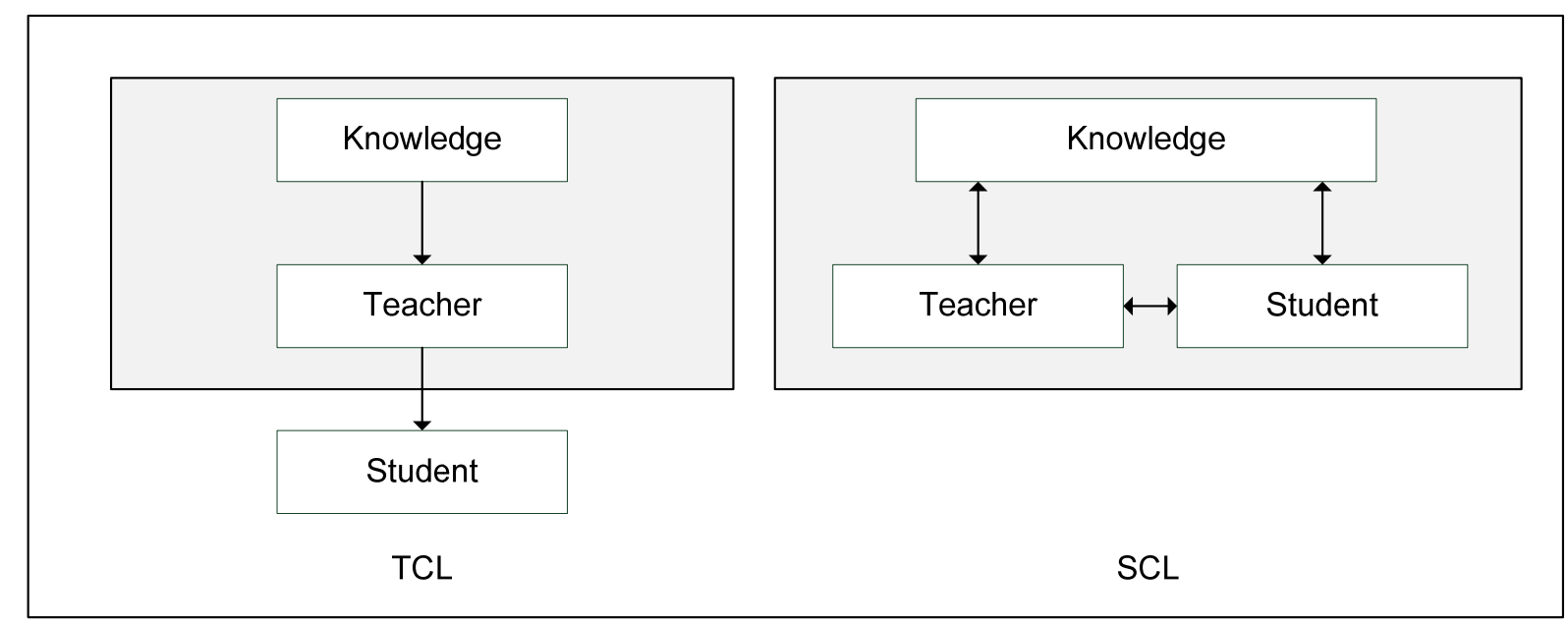

Figure 1: Comparison of TCL and SCL (Suwardjono, 2005)

The nature of human beings is to tell or share something that they know. When teachers gain knowledge through reading or research, they have the tendency to convey this knowledge to the student. There is nothing wrong with this drive; however the tendency to transmit all the details of the knowledge to students will become a problem for students' future learning. When students' knowledge is acquired only by receiving from the teacher, the student will become a passive receiver and will not experience the true learning process. The genuine nature of learning is through discovery of new things by themselves.

\section{Shifting from TCL to SCL}

Shifting from teacher-centred to student-centred learning is not a simple transition. It is more appropriate to be noted as an attempt to change one's paradigm, from the teacher-centred paradigm to the student-centred paradigm. Barr (1998) stated that the shift of paradigm is difficult not only for intellectual reasons but also because of some psychological reasons. Cognitive psychology has long noted that prior beliefs are often a major barrier to 
subsequent learning. Once human beings think that they have figured something out, they want to see and hear things that confirm their beliefs. Teachers who are based in a teacher-centred paradigm believe that lecturing is the best way of delivering knowledge in education. They often argue: "It has always been this way and it works, so why bother to change it?” This kind of psychological barrier hinders the opportunity to see the possibility of other methods of teaching and learning.

The resistance to change is known in social psychology as a result of a phenomenon called belief perseverance (Grant, 2003). Belief perseverance is the tendency to adhere to one's initial belief even after receiving new information that contradicts or disconfirms the basis of that belief (Anderson, 2007).

Change rarely occurs voluntarily in private enterprises and even less so in public institutions (Fremerey, 2006). This fact is explained with a basic human desire for safety and preservation of the status quo. In the setting of higher education institutions, academic staffs often do not fully identify with the university as their organization. Therefore, they might be reluctant to change because they regard organizational change either as an issue which does not concern them or as a potential threat against their autonomy.

In terms of changing from TCL to SCL, lecturing has been a method of delivering knowledge for years, and often teachers somehow blend this method into their self identity. Teachers see themselves as the source of knowledge and believe they should transfer knowledge to the student by lecturing. To some extent there is a sense of fear from the teacher in the implementation of SCL. Teachers fear that they will become less important in the learning process.

Schein (1972) introduced the term learning anxiety which reflects the hesitation to change. Learning anxiety prevents us from committing to change, and causes us to react defensively against change. Learning anxiety is the feeling that if we allow ourselves to enter a learning or change process, if we admit to ourselves and others that something is wrong or imperfect, we will lose our effectiveness, our self-esteem and maybe even our identity. It is the nature of human being to see themselves doing their best at all times. To admit that one is doing something in an ineffective way requires some wisdom that not everybody can afford.

\section{The Case of Gadjah Mada University}

Founded in 1948, Gadjah Mada University (UGM) is one of the oldest higher education institutions in Indonesia. Located in the city of Yogyakarta, UGM is also one of the biggest universities in Indonesia with 18 faculties and around 55 thousand students.

One of the main targets of UGM's strategic plan for 2003-2007 was to improve the quality of the learning process (UGM, 2004a). In this strategic plan, UGM stated clearly that the university's goal was to improve the quality and the relevance of education; and to apply an education paradigm that is based on student-centred learning. Furthermore, in the guidance of academics action, UGM determined to implement a curriculum that is based on competence and to create an academic process which is interactive, innovative, dynamic, and 
capable of creating lifelong learners (UGM, 2005).

In the year of 2002/2003, UGM conducted the first university-level graduate survey. More than 2,000 graduates and 60 employers were surveyed. The main objective of this graduate survey was to identify the quality of UGM graduates in the labour market. More specific objectives of the survey were: to identify the competence of graduates; to identify the relevance of the curriculum to the labour market demand; and to determine the labour market demand and the competencies needed (UGM, 2004b).

After analyzing the data, UGM became more determined to implement SCL in the curriculum. Graduates' data showed that graduates were lacking some soft skills. Employer's data also showed that compared to other universities, UGM's graduates needed to improve their soft skills such as communication, entrepreneurship, creativity, innovation, leadership and negotiation skills (UGM, 2004b).

These soft skills are not something that can be taught in the classroom. Higher education institutions can develop courses to prepare students to acquire soft skills, however the desired outcome will not be reached. Therefore, the development of soft skills should be acquired through application in the curriculum. Soft skills should be integrated in the curriculum which means that all subjects should produce soft skills "side effects" for the students.

In order to accelerate the implementation of SCL in UGM, a new study centre was founded: Pusat Pengembangan Pendidikan (P3-UGM) or Centre for Education Development (CED). The main task of this centre was to define strategy and planning of education development in UGM. The second task was to develop a strategy to increase the quality of education. The final task was to conduct an education quality monitoring system. This centre will periodically report directly to the university president. CED was the main actor in the process of shifting from TCL to SCL in UGM.

The first step of the SCL implementation was to conduct university-wide SCL workshop. Each faculty sent two representatives to this workshop, and was encouraged to send their junior lecturers. This three-day workshop was constructed based on the theory of experiential learning. This meant that the participants were themselves experiencing the essence of SCL. Several role-playing activities were designed, and at the end of each role-playing session, the participants had to reflect and share what they had just experienced. Afterwards, the facilitator summed up the session by connecting what they have just done with the theory and best-practice examples. The workshop consisted of role-playing in cooperative learning, collaborative learning, competitive learning, case-based learning and problem-based learning. Other essential sessions were a shifting-paradigm session, a group-dynamics session, a good-facilitator session and an additional session on how to create a problem-based learning scenario.

The next step was conducting the workshop at the individual faculty level. The CED team visited each faculty to conduct the same SCL workshop. The participants were lecturers in the faculty and the situation was different from one faculty to another. Some faculty made a clear command that each lecturer should attend this workshop while others made it 
voluntary. CED came to the faculty only when the faculty invited them. The university suggested that all faculties should invite the CED to conduct the workshop in their faculty but the final decision was in the dean's hand.

UGM also had a special grant for lecturers who implement SCL principles in their course, putting their idea of SCL implementation in the syllabus. After the university conducted the selection process the lecturer would get the grant. The selection process was concerned with the overall appropriateness of SCL implementation to the subject. In the year 2007, there were 35 grantees.

\section{Discussions}

Application of SCL cannot be achieved only by a jargon campaign. To shift from TCL to SCL basically means that a lecturer's overt behaviour needs to be changed; changing overt behaviour cannot be achieved only by changing an attitude. Often, the change process in an organization does not work because managers believe that by changing the attitude they will change the overt behaviour. However the correlation between attitude change and behaviour change is quite low (Cooper, 1994).

Universities can create a campaign to promote the benefits of SCL for the lecturers and students. They can make articles, colloquiums, seminars, meetings and other gatherings to persuade the lecturers to implement SCL. However the result will not be optimal. The lecturer may learn that TCL is less effective than SCL, but they might continue to use TCL for many reasons. At UGM, CED was aware of this condition and set up a strategy for the process of shifting from TCL to SCL. With the SCL workshop, CED created the atmosphere of SCL for the lecturers, and the lecturers experienced the excitement of SCL for themselves.

The SCL workshops had several significant functions in the shifting process from TCL to SCL:

1. The workshops constructed the same conception about SCL among all participants. From reading and personal experience, lecturers may have already prior-knowledge about SCL. However, sometimes this prior knowledge is wrong or misleading. The workshop set the starting point for each participant at the same level. A common point of misleading prior knowledge is that SCL is associated with high-tech learning process such as using computers, projectors or other electronic gadgets as a teaching medium. Another misconception is that SCL is only for small classes. Lecturers complain that they cannot implement SCL because they have big classes.

2. The workshop set up the base for achieving the goals, to shift from TCL to SCL. To achieve a goal, one must determine the current position and establish where to end up. Through the workshop the participants realized that in their current situation, they were still using TCL and that this method was no longer suitable for students. It was proven by the decreasing quality of students' final papers and overall student performance. After determining the current position, a specific goal was set, which was the implementation of SCL. Making the objective clear is very important in the change process. As goal setting 
theory suggests, the goal should be challenging (not too easy) but still achievable (not too difficult) (Schermerhorn, 1996). The workshop confirmed that implementing SCL is achievable, and is possible in a large class and without high tech gadgets and technology.

3. The SCL workshop, especially in the individual faculty-level, was also the first step in dealing with resistance. As noted by Fremerey (2006), in working with resistance, the necessary steps that should be taken are: surface the resistance, acknowledge the resistance, explore the reasons for resistance, and explore potential benefits of resistance. No matter how hard the resistance is, if we can make it communicable, we also will be able to manage it. The process of making it communicable will be the first step to acknowledging the resistance. The resister should know that his/her attitude and argument are not plainly rejected. If the resister believes that they are being acknowledged by the organization (university/faculty), the process of fruitful discussion will start. The discussion will explore the resister's reasons and motives. By studying the resister's opinion, the university may also receive new insight that will be useful in the change process. Through these processes the resisters will have a feeling of acceptance; even if their opinion is rejected at the end, the resistance power will be considerably softened.

4. The SCL workshop also addressed the ready-to-change lecturers. These lecturers already have the drive to change since they feel that lecturing is no longer sufficient for the current situation. However, they did not know how to implement SCL. The workshop supported the ready-to-change lecturers with step-by-step implementation of SCL.

UGM's decision to first hold the university-wide SCL workshop followed by the individual faculty level workshop was reasonable. The university cannot just command faculties to implement SCL in the curriculum. Rather, by holding the university-wide workshop, the university created an agent of change in every faculty. The university was fully aware of the unique characteristics of higher education institutions as presented in the introduction. If the university had directly obligated the faculty to implement SCL, the chances of success would be slim, and there is a high probability that there will be more resistance emerging. A lot of faculties (and moreover the lecturers) would have felt that the university was intruding on their professionalism and academic freedom, or that the university was trying to teach them how to teach, a task in which they feel that they have the best capability.

It should also be noted that UGM encouraged the faculties to send their junior staff. This was based on the belief that the junior staff will be more flexible in handling changes. Junior staff usually has a higher motivation in learning new knowledge compared to their senior colleagues. The enthusiasm to learn made them more open to change. After receiving new knowledge of SCL, the junior lecturers would be tempted to implement them in their class. White's well known analysis (as cited in Davis, 1979) states that competencies are motivational: if one individual learn new skills, he/she will naturally want to apply them. Therefore, after the junior lecturers attended the workshop they would likely be motivated to implement what they have learned, regardless of support from the faculty. The implementation of SCL in UGM was basically focussed on the individual level; therefore if 
the faculty does not support them, the lecturer could implement SCL in their own courses.

The other reason why the university did not oblige faculties (or lecturers) to implement SCL was because the university considered the share of ownership of the change process. If the lecturer felt that the shifting process to SCL was mainly an order from more superior person in the hierarchy, they were more likely to resist. However if the initiation of change was started from themselves, the lecturer would see this situation in a different way. Instead of thinking that the change process came from the university, they would see the process as their personal goal. When an organization's goal is integrated with an individual's personal goal, the possibility for success will be greater. As also noted by Fullan \& Stiegelbauer (1991), one of the characteristics of a successful change process is the role of ownership. Ownership is not something that emerges magically; rather it comes out during a successful change process.

As mentioned earlier, an attitude change will not automatically lead to behavioural change. Lecturers may have learnt that TCL is less effective than SCL, but they might continue to use TCL for many reasons. One of the reasons could be the group acceptance aspect (Muchinsky, 1987). Lecturers may feel hesitant to implement SCL simply because none of their colleagues are implementing it in their courses. They may be afraid that being different (by implementing SCL in their course) will decrease the group acceptance of their colleagues, more so when the faculty does not give any support or any interest at all for SCL.

The inconsistency between what the lecturers know and what they do was addressed by UGM with the introduction of motivational concepts. UGM's creation of a grant for lecturers who implement SCL principles in their courses was a good application of motivational concepts. Hull's equation (as cited in Davis, 1979) in describing the relationship between learning and motivation seems to fit in explaining the situation. Hull's equation proposed that the strength of the tendency to perform $(\mathrm{P})$ is a function of habit $(\mathrm{H})$ or prior learning multiplied by drive (D) and incentives (I). Individual is not just "pushed" into action by drive, but they also "pulled" by incentives. The lecturers already have the drive (to implement a better learning method) and the prior knowledge (from the SCL workshop). The introduction of incentives (I) will multiplied the effect of change. With the establishment of the SCL grant, UGM increased the chances of a successful change process.

In the case of UGM the grant was not merely an incentive for the lecturer, but also a kind of quality control for the implementation of SCL. To really measure the progress of the SCL implementation in the curriculum is not easy. The university cannot just barge into a classroom to check the implementation. As mentioned earlier, as professional employees, university academic staff demands work autonomy and freedom from supervision; they base their work on skills and expertise and demand autonomy to apply them. If they feel that the university wants to control their work, the result will be counter-productive for the change process.

With this grant program the university also attempted to release the lecturer from the faculty frame. The lecturer would be motivated to implement SCL regardless of the existence of faculty support. Later on, these lecturers might become agents of change and encourage 
the faculty dean to arrange the SCL workshop in the faculty level. Implementation of SCL workshop in the faculty level means acceleration in the change process. Concerning this situation, Laske gives a well-phrased outlook:

In a social system which is strongly characterized by individual freedom, change will happen only when enough members of the system can agree on a guiding melody. They start humming the melody gently. When the melody has become catching or thrilling, even Professors may start to dance. (Laske as cited in Fremerey, 2006, p. 13)

As the implementation of SCL spreads, the group acceptance aspect will become a reinforcement rather than a barrier. At first lecturers may hesitate to implement SCL because none of their colleagues are implementing, yet as the implementation of SCL spreads, the condition is the other way around. A lecturer who does not implement SCL will have some kind of social pressure when all other colleagues have already implemented.

The case of implementation of SCL in UGM was an example of a successful change process. Fullan and Stiegelbauer (1991) propose some features for successful change: first, to make change happen requires active initiation and participation. Small groups of individuals must begin and then as the process of change is underway, momentum for change builds up. UGM tried to foster change not only top-down but also bottom-up. UGM designed a change process that can be started both from the faculty and also from each individual (lecturer) regardless of the commitment of the faculty. With this bottom-up change process, the process of change was more manageable on the side of the lecturer.

Second, the role of pressure and reinforcement is necessary for the change process (Fullan \& Stiegelbauer, 1991). After the behaviouristic psychology era, pressure is considered an inappropriate tool in behaviour change process. However there are many positive functions for pressure in the change process. When pressure is combined with support, the power of change will be bigger than the forces of status quo. Thus the change process will flow. In UGM's case, the pressure was obvious. UGM did not create apparent pressure such as punishment for the lecturer if they do not implement SCL. In the university context, where professionalism is highly valued, punishment is something that obviously would not work. Instead, UGM created a different kind of pressure for the lecturer in the dissemination process of SCL implementation. In academic policy, the strategic planning, the periodical newsletter, the website, and in official-meetings or other ceremonies, UGM declared clearly that the university will implement SCL in the teaching and learning process. Other pressure was from social acceptance. As mentioned before, when the change program has begun and more and more lecturers implement SCL in their subjects, lecturers who do not implement SCL will feel some pressure from their colleagues. The same pressure might be also come from students who demand some changes in the method of teaching and learning. As for the reinforcement, it was clear that the university had supported the change process. Founding the CED, conducting the workshops, providing related information for the lecturers, and creating the SCL grant were some of the ways UGM gathered support for the change process.

Third, the relationship between changes in behaviour and changes in belief or attitude 
requires careful consideration (Fullan \& Stiegelbauer, 1991). As also noted by Cooper (1994), a change of attitude is not automatically followed by a change of behaviour. Hence changing behaviour cannot be accomplished only by a jargon campaign. UGM understood this clearly and implemented the workshop in an experiential learning model so the lecturers experienced directly a SCL environment instead of just a jargon campaign.

The role of ownership is the fourth features of a successful change process (Fullan \& Stiegelbauer, 1991). As mentioned before, when an organization's goal is integrated with the individual's personal goal, the possibility for success will be higher. In UGM's case the university was not directly commanding the faculty or the lecturer to use SCL. UGM designed the process of change so the lecturer can have control over the change process. In the end it was not the university who decided to change, but the lecturers themselves. This, to some extent, gave the lecturers a sense of ownership in the change process.

\section{Conclusion}

Based on Fullan and Stiegelbauer's (1991) criteria of successful change, the implementation of student-centred learning in the University of Gadjah Mada was an example of good practices of change management in the higher education context. However there are some aspects that could have been improved. In UGM's case there were not any significant problems with the students. The students quickly adapted to the new teaching and learning method. However, because they had been taught with the TCL method in their primary and secondary education, the process of adaptation took some time. Ideally, students would have already experienced SCL in primary and secondary education. With this condition, the students would adapt to SCL faster in university. Since the early 1990's, the government of Indonesia has started the principle of active learning in the primary and secondary education curriculum. However the implementation is still far from optimal. It is in the best interest of students for the government to re-evaluate this program and improve it so the primary and secondary education will also have the essence of SCL.

To change from TCL to SCL is no longer an option but a must. From time to time universities are facing new challenges and are always responsively changing accordingly. However in terms of teaching and learning, it seems that universities are reluctant to change. Students are also facing new challenges in the future that one cannot even imagine at the present time. The following question from Senge (2000, p. 275) should be in the mind of every lecturer: "Are we preparing students for the future they will live in or the past we have lived through?"

\section{References}

Anderson, C. A. (2007). Belief perseverance. In R. F. Baumeister \& K. D. Vohs (Eds.), Encyclopedia of Social Psychology (pp. 109-110). Thousand Oaks, CA: Sage.

Baldridge, J. V. (1983). Organizational characteristics of colleges and universities. In J. V. 
Baldridge \& T. Deal (Eds.), The dynamics of organizational change in education (pp. 38-59). Berkeley: McCutchan.

Baldridge, J. V., Curtis, D. V., Ecker, G. P., \& Riley, G. L. (1982). Alternative models of governance in higher education. In G. L. Riley \& J. V. Baldridge (Eds.), Governing academic organizations (pp. 2-25). Berkeley, CA: McCutchan Publishing Corporation.

Barr, R. B. (1998). Obstacles to implementing the learning paradigm--What it takes to overcome them. About Campus, 3(4), 18-25.

Birnbaum, R. (1989). The cybernetic institution: Toward an integration of governance theories. Higher Education, 18(2), 239-253. http://dx.doi.org/10.1007/bf00139183

Bonwell, C. C., \& Eison, J. A. (1991). Active learning: Creating excitement in the classroom. ERIC Digest. ASHEERIC Higher Education Reports The George Washington University. Retrieved from http://www.oid.ucla.edu/about/units/tatp/old/lounge/pedagogy/downloads/active-learnin g-eric.pdf

Boyapati, E. (2000). Learning: Student-centred vs teacher-centred. Korean Journal of Chemical Engineering, 17(3), 365-367. http://dx.doi.org/10.1007/BF02699054

Brandes, D., \& Ginnis, P. (1986). A guide to student-centred learning. London: Basil Blackwell Ltd.

Brush, T., \& Saye, J. (2000). Implementation and evaluation of a student-centered learning unit: A case study. Educational Technology Research and Development, 48(3), 79-100. http://dx.doi.org/10.1007/BF02319859

Cannon, R., \& Newble, D. (2000). A guide to improving teaching methods: A handbook for teachers in university and colleges. London: Kogan Page.

Chickering, A. W., \& Gamson, Z. F. (1991). Seven principles for good practice in undergraduate education. New Directions for Teaching and Learning, 1991(47), 63-69. http://dx.doi.org/10.1016/0307-4412(89)90094-0

Cohen, M. D., March, J. G., \& Olsen, J. P. (1972). A garbage can model of organizational choice. Administrative Science Quarterly, 17(1), 1-25. http://dx.doi.org/10.2307/2392088

Cooper, D. (1994). Implementing the behaviour-based approach: A practical guide. The Health And Safety Practitioner, 12(11), 18-23.

Davis, R. H. (1979). A behavioral change model with implications for faculty development. Higher Education, 8(2), 123-140. http://dx.doi.org/10.1007/BF00138376

Elton, L. (1999). New ways of learning in higher education: Managing the change. Tertiary Education and Management, 5(3), 207-225. http://dx.doi.org/10.1023/A:1018773506442

Elton, L. (2003). Dissemination of innovations in higher education: A change theory approach. $\begin{array}{llll}\text { Tertiary Education } \quad \text { and } & \text { 9(3), }\end{array}$ 
http://dx.doi.org/10.1080/13583883.2003.9967104

Fay, P. (1988). Open and student centred learning: Evangelism and Heresy. Journal of Further and Higher Education, 12(1), 3 - 19. http://dx.doi.org/10.1080/0309877880120101

Findlow, S. (2012). Higher education change and professional-academic identity in newly 'academic' disciplines: the case of nurse education. Higher Education, 63(1), 117-133. http://dx.doi.org/10.1007/s10734-011-9449-4

Fremerey, M. (2006). Resistance to change in higher education: Threat or opportunity? In M. Fremerey \& M. Pletsch-Betancourt (Eds.), Prospects of change in higher education: Towards new qualities \& relevance (pp. 217-230). Frankfurt: IKO-Vlg fur Interkult, GW/Transaction Pubs.

Fullan, M. G., \& Stiegelbauer, S. (1991). The new meaning of educational change(2nd ed). New York: Teachers College Press.

Geven, K., \& Attard, A. (2012). Time for Student-Centred Learning? In A. Curaj, P. Scott, L. Vlasceanu \& L. Wilson (Eds.), European Higher Education at the Crossroads (pp. 153-172). Amsterdam: Springer Netherlands. http://dx.doi.org/10.1007/978-94-007-3937-6_9

Giesecke, J. (1991). Creativity and innovation in an Organized Anarchy. Journal of Library Administration, 14(2), 59-71. http://dx.doi.org/10.1300/J111v14n02_05

Glassman, R. B. (1973). Persistence and loose coupling in living systems. Behavioral Science, 18(2), 83-98. http://dx.doi.org/10.1002/bs.3830180202

Grant, K. (2003). Making sense of education change at Thistle College: The existence of witchcraft, witches and shamans. The International Journal of Educational Management, 17(2/3), 71-83. http://dx.doi.org/10.1108/09513540310460261

Guskin, A. E. (1996). Facing the future: The change process in restructuring universities. Change, 28(4), 26-37.

Lea, S. J., Stephenson, D., \& Troy, J. (2003). Higher education students' attitudes to student-centred learning: Beyond 'educational bulimia'? Studies in Higher Education, 28(3), 321 - 334. http://dx.doi.org/10.1080/03075070309293

Muchinsky, P. M. (1987). Psychology applied to work. Chicago: Dorsey Press.

Rebora, G., \& Turri, M. (2010). Change management in universities: More a question of balance than a pathway. Tertiary Education and Management, 16(4), 285-302. http://dx.doi.org/10.1080/13583883.2010.529162

Schein, E. H. (1972). Change mechanism. In W. G. Bennis, K. D. Benne \& R. Chin (Eds.), The Planning of Change (3rd ed.). New York: Holt Rinehart.

Schermerhorn, J. R. J. (1996). Management (5th ed.). New York: John Wiley \& Sons.

Senge, P. M. (2000). The academy as learning community: Contradiction in term of realizable 
future? In A. F. Lucas (Ed.), Leading Academic Change: Essential Roles for Department Chairs (pp. 275-300). San Francisco: Jossey-Bass Publishers.

Suwardjono. (2005). Belajar-mengajar di perguruan tinggi: Redefinisi makna kuliah. [Teaching and learning in higher education: Redefinition of class-meeting meaning]. Retrieved from http://www.inparametric.com/bhinablog/download/Artikel1.pdf

UGM. (2004a). Rencana strategis Universitas Gadjah Mada tahun 2003-2007. [Gadjah Mada University's strategic planning 2003-2007]. Retrieved from http://www.ugm.ac.id/downloads/RenstraUGM2003-2007Revisi25April2004.pdf

UGM. (2004b). Tracer study dan labor market signal bagi lulusan Universitas Gadjah Mada. [Tracer study and labour market signal for Gadjah Mada University's graduates]. Gadjah Mada University.

UGM. (2005). Kebijakan akademik Universitas Gadjah Mada tahun 2005-2010. [Gadjah Mada University's academic policy 2005-2010]. Retrieved from http://www.ugm.ac.id/downloads/Kebijakan-Akademik-Universitas-2005-2010.pdf

Vaatstra, R., \& De Vries, R. (2007). The effect of the learning environment on competences and training for the workplace according to graduates. Higher Education, 53(3), 335-357. http://dx.doi.org/10.1007/s10734-005-2413-4

Weick, K. E. (1976). Educational organizations as loosely coupled systems. Administrative Science Quarterly, 21(1), 1-19.

\section{Copyright Disclaimer}

Copyright reserved by the author(s).

This article is an open-access article distributed under the terms and conditions of the Creative Commons Attribution license (http://creativecommons.org/licenses/by/3.0/). 